\title{
Language policy, in-migration and discursive debates in Wales
}

\author{
Catrin Wyn Edwards ${ }^{1}$
}

Received: 14 January 2015/Accepted: 26 January 2016/Published online: 4 March 2016

(C) The Author(s) 2016. This article is published with open access at Springerlink.com

\begin{abstract}
Drawing on theory from critical language policy literature, this article explores the impact of discourses on in-migration on Welsh language policy. By focussing on discursive debates surrounding the subject of in-migration, the article analyses how a range of actors produce and reproduce discourses on in-migration in Wales and how these discursive struggles impact on policy. It argues that, while certain actors have been able to construct a powerful discourse on in-migration through language debates, others have failed to make their voices heard and their views on the subject have been silenced. This unequal access to the production of discourse is not incidental; it is indicative of wider power structures at play within bilingual or multilingual language communities. Therefore, while the study focusses on Wales, the article highlights a theme that is relevant to all minoritized language groups, that of the interrelationship between policy, politics and power. It also stresses the importance of adopting an approach to language policy that takes into account both structure and agency alike, and confirms that language groups should not be conceptualised by number of speakers using categories such as 'dominant', 'subordinate', 'majority' and 'minority', but rather by issues of power and status.
\end{abstract}

Keywords Welsh Language · In-Migration · Discourse · Language Policy · Wales · Plaid Cymru · Welsh Labour Party

Catrin Wyn Edwards

cwe6@aber.ac.uk

1 Department of International Politics, Aberystwyth University, Penglais, Aberystwyth SY23 3FE, Wales, UK 


\section{Introduction}

In 1986, Meredydd Evans, as President of the day at the annual Eisteddfod Genedlaethol, delivered a speech on the subject of in-migration. During his talk, he encouraged politicians and members of the Welsh language community to start an open and responsible discussion on the impact of in-migration from England on the Welsh language in rural Wales, and argued that local councillors and politicians had avoided the subject thus far for fear of losing political votes (see Ffrancon and Jenkins 1994, 350-351). While his speech was well received among the Welshspeaking audience, the media in Wales portrayed it in a more negative manner, with two of Wales' main daily papers, the Western Mail and the Daily Post sensationalising the lecture. The following day, Meredydd Evans' speech made front page news with the Daily Post reporting that:

Passport control to enter Gwynedd comes ever nearer-if the self important Eisteddfod clique is to be believed...This veteran of Triawd y Coleg entertained his audience with a quixotic call for community control of 'foreign' immigration. ${ }^{1}$ In the context of his speech, 'foreign' meant anyone from outside the borders of any self-defined Welsh ghetto. He made the sinister plea for citizens to play their part by forgetting 'the ordinary rule of courtesy to newcomers' (Wynne Jones 1986: 1).

The Western Mail also reported that Meredydd Evans had advocated strict immigration laws 'to combat the massive threat to the Welsh language by a flood of foreign influences' and had encouraged an 'immigrant curb' to save the Welsh language (Hewitt 1986: 1).

It is now 30 years since Meredydd Evans encouraged Welsh speakers and politicians to speak out about the influence of in-migration on the Welsh language. However, while there is now greater support for the Welsh language and inmigration continues to represent a challenge for those working to protect the language, politicians in Wales continue to avoid discussing in-migration publicly. In addition, Welsh speakers have not developed a strong enough voice to articulate their views on the issue. This article explores why the subject of in-migration has been characterised by silence and reluctance.

The article has manifold contributions. First and foremost, it responds to recent critiques of the 'historical-structural' approach by adopting a discourse analytic approach that focusses on the agents, contexts and policy processes across multiple layers, while simultaneously giving adequate attention to the wider power structures at play in policy-making processes. By doing so, the analysis provides an important balance between structure and agency, thus making an important contribution to extant theoretical discussions on language ideological debates and discourses in the critical language policy literature. It argues that, although language ideologies and discourses are undoubtedly bound up in wider historical and socio-political

\footnotetext{
1 Along with Cledwyn Jones and Robin Williams, Meredydd Evans was a member of the Triawdy Coleg (literally 'The College Trio') folk group, which was popular within the Welsh language music scene during the 1940s and 1950s.
} 
processes and power structures that are often macro in essence, it is also essential to account for the complex power dynamics that exist between various actors on a micro level. Language policy agents may be empowered and able to challenge hegemonic language practices; nevertheless, it is important to understand this in the context of wider power structures and relationships.

The article applies theoretical discussions on language ideologies and discourses in the language policy literature to the case of Wales. This has both empirical and analytical value for the study of Wales as well as the field of language policy in general. Thus far, apart from contributions from Brooks (2006), Royles (2007) and Wyn Jones (2014), which provide an account of the discussion on in-migration on a party political and civil society level in Wales, and a study by Milani et al. (2011), which analyses a language ideological debate on the Welsh language in the context of a BBC website, there has been little in the way of analysis of the interrelationship between language debates, discourses and language policy in the field of in-migration. ${ }^{2}$ This is in spite of the fact that commentators have partly attributed the decrease in the percentage of people able to speak Welsh on Wales-wide level to in-migration (Jones 2012).

The article, therefore, leads to a greater understanding of the political and power dynamics at play during discursive debates on the Welsh language and in-migration. It identifies the contexts under which language and in-migration become important themes and objects of politization and polarisation, and illustrates how political discourses and agendas subsequently influence on policy processes. Therefore, by analysing the link between different discourses and broader political developments in Wales and situating this within existing academic discussions on power and discourse, the article also makes a valuable contribution to policy in Wales. Furthermore, it is relevant to both policy-makers and academics working on issues relating to minority language sustainability beyond Wales and the UK.

The article focusses on responses to the integration of adult in-migrants in Wales across multiple layers. ${ }^{3}$ This has two main advantages: first, analysing the nature of debates and discourses on in-migration and language on a Wales-wide level facilitates a greater understanding of the interrelationship between politics, power and agency. Second, concentrating on the local level reveals how discursive debates on a macro level play out in practice. In addition, the varied socio-linguistic context in Wales means that certain areas of Wales feel the effects of in-migration from the rest of the UK more acutely. This article concentrates on north-west Wales, where there has been considerably more policy action and in-migration, as a means to exemplify how discursive debates can impact on policy.

The article draws on data gathered and corroborated through two methods; a thematic analysis of policy plans and strategies published by governmental and non-

\footnotetext{
2 Milani et al. (2011) analyse the website of the BBC 'Voices' project by using language ideology and the analytical tools of multimodal CDA. The main argument advanced is that there is a continual tension between centripetal (unifying) and centrifugal (particularising) forces. These forces aim for the creation of national identities that are conflicting and contrasting in nature.

3 The article focusses on policies and measures that have been designed specifically for in-migrants. For this reason, the article does not analyse the work of Welsh for Adults Centres, who do not explicitly differentiate between in-migrants and non-Welsh speaking in their provision (Welsh Government, Interview 3, 2011; North Wales Welsh for Adults Centre, Interview 9, 2012).
} 
governmental organisations and semi-structured interviews conducted in Wales. ${ }^{4}$ Data collected and analysed through these two methods are presented and discussed alongside each other throughout the paper.

The article first positions the study within the larger field of inquiry on language politics and engages with theories in critical language policy and themes from the field of critical discourse analysis (CDA). It then develops to provide an in-depth empirical discussion on how discourses around the Welsh language, in-migration and Welsh language policy are being formed, articulated and reinforced. The final section of the article shows how debates and discourses on in-migration in Wales have influenced on the policy measures formulated and implemented in the field.

\section{Theoretical framework}

This section presents an overview of some of the key arguments on discourse, power and politics in the interdisciplinary field of CDA and the language policy literature. It then provides an explanation for adopting a critical approach to language policy that concentrates on both structure and agency.

The study of language policy has evolved considerably over the course of the last 50 years; while the 'neo-classical approach' characterised the field of language policy studies in the 1960s and early 1970s (Tollefson 1991), the 1990s witnessed the development of a new approach, which was influenced by critical theory. ${ }^{5}$ This 'historical-structural' approach continued to focus on state policies and institutions, but concentrated on the power and inequality dimension of language policy, arguing that language policies were instruments that reaffirmed unequal power structures and relationships (Tollefson 1991, 1995). The approach affirms that 'all language plans and policies represent and reflect the sociopolitical and economic interests of majoritarian or dominant interests; that these interests are often implicit and are enmeshed in hegemonic ideologies that serve to maintain the socioeconomic interests of ruling elites [...] and that 'that individuals are not free to choose the language(s) that they will be educated in or be able to use in specified domains' (Ricento and Hornberger 1996: 407).

This development in language policy studies coincided with the development of CDA. ${ }^{6}$ Now an established academic discipline, CDA is based on three key concepts: power, ideology and critique (Wodak and Meyer 2009: 1) and emphasises 'language as social practice' (Fairclough 1989; Fairclough and Wodak 1997). ${ }^{7}$ In the field of CDA, discourse is defined as follows:

socially constitutive as well as socially conditioned-it constitutes situations, objects of knowledge, and the social identities of and relationships between

\footnotetext{
4 Approximately 20 semi-structured interviews were conducted with politicians, policy-makers, civil society actors and language and educational practitioners.

5 See Tollefson (2013: 26) for a discussion on the limits of the 'neo-classical' approach.

6 See Blommaert (2005: 22-26) for a discussion on the origins of CDA.

7 Fairclough provides a three-dimensional framework for conceiving of, and analysing discourse: discourse-as-text, discourse-as-discursive practice, and discourse-as-social-practice (1992).
} 
people. It is constitutive both in the sense that it helps to sustain and reproduce the social status quo, and in the sense it contributes to transforming it. Since discourse is so socially consequential, it gives rise to important issues of power. Discursive practices may have major ideological effects-that is, they can help produce and reproduce unequal power relations between (for instance) social classes, women and men, and ethnic/cultural majorities and minorities through the ways in which they represent things and position people (Fairclough and Wodak 1997: 258).

Perceiving discourse as a social practice suggests that there is 'a dialectical relationship between a particular discursive event and the situation (s), institution (s) and social structure (s), which frame it' (ibid. 258).

Analysing specific discursive events, such as debates, through CDA not only exposes the power of discourse, but also who retains 'power over discourse' (Jager and Maier 2009: 37). While discourses are 'supra-individual' and no one individual or group has complete control over the development of discourse and its final result (Fairclough 1989: 43; Jager and Maier 2009: 37-39) some individuals or groups have greater ability to influence political discourse. Jager and Maier (2009:37-39) argue that: in the long run, powerful politicians and other groups can accomplish changes in discourse. [...] Certain groups and individuals have more power over discourse than others, for example because they have privileged access to the media or greater financial resources'. Fairclough also argues that power can be 'in' or 'behind' discourse and states that the nature of the power relations in mass media is 'hidden' (1989: 43). Therefore, by focussing on discursive debates in a diachronic manner, it is possible to explore the role of different political and social actors in the creation of particular discourses and ascertain which actors have greater ability to influence on discourse.

Ideology and discourse is also tied to the analysis of power relations in discussions on language policy and language-in-education policy (e.g. Tollefson 1991, 1995, 2002; Ricento 2006). Tollefson (1995: 2) links ideology and the analysis of power relations to language-in-education policy and claims that power can be discursive, ideological or state-based. For Tollefson, understanding the interrelationship between policy and ideology is crucial when exploring "policymaking processes, constraints on policy alternatives, and the socially constructed meanings of specific policies and practices' (2013: 3).

Blommaert $(1999,2005)$ also adopts a critical, historical approach to languagein-education policy and language policy and highlights the relationship between power, discursive struggle and language. Nevertheless, there are tensions between CDA and Blommaert's approach, with Blommaert advancing a number of critiques of CDA (see Blommaert 2005: 50-53; Blommaert and Bulcaen 2000: 447-466). ${ }^{8}$ Blommaert's theory on language ideological debates provides a valuable discussion on the politics of language and shows how human agency, political intervention, and

\footnotetext{
8 Amongst other critiques, Blommaert (2005: 50-51) advances that: 'One the most important methodological problems in discourse analysis in general is the framing of discourse in particular selections of contexts, the relevance of which is established by the researcher but is not made into an object of investigation. [...] In CDA, discourse in accompanied by a narrative on power and institutions, large portions of which are just copied from rank-and-file sources or inspired by received wisdom'.
} 
power and authority are all part of the history of languages. With the participation of a number of social actors, these debates can reproduce, reinforce and amend ideologies and fall into two broad categories: 'formative' and 'inconsequential'. While 'formative' debates can 'instigate implementation practices and hegemonize the field', 'inconsequential' debates fail to challenge power structures or relations. However, these 'inconsequential' debates are crucial to understanding the political and ideological traditions at play in a society (1999: 10). Debates, therefore, are illustrative of power.

Blommaert (1999: 8) asserts that there is an explanation why the voices of certain groups or individuals go unheard or are silenced and that this is not purely synchronic'. Rather, 'it usually has to do with slowly or dramatically emerged forms of inequality sedimented in the differential allocation of speaking rights, attributions of status and value to speech styles, uneven distribution of speech repertoires and other historical developments'. Thus, analysing the development of debates, ideologies and discourses uncovers broader socio-political processes. It also facilitates a greater understanding of how different actors such as politicians, policymakers, the media and members of the public are involved in processes of power and in contributing towards ideologies and discourses through debates. Consequently, language policy scholars need to adopt a 'materialist' approach to the analysis of policy that takes into account the 'real social actors' (Blommaert 1999, 2005).

Blackledge also provides a valuable contribution to the discussion on discourse and power in multilingual communities, and has attempted to bridge discussions on CDA with language ideology debates, drawing attention to the potentially complementary aspects of these two theoretical approaches. Blackledge argues that power and debates on language are closely associated, and that ideologies are developed through discourse. The exact nature of these discourses varies; they can be 'explicit and implicit, visible and invisible, official and unofficial, long-term and ephemeral, contested and uncontested, negotiable and non-negotiable'. Such ideologies are reinforced, inter alia, through discourses in news media, politics, advertising, academia and popular culture (2005: 44). They can act as mechanisms that establish, maintain and strengthen boundaries between people across different levels in a broad range of contexts (Blackledge and Pavlenko in Blackledge 2005: 44).

Over the decades, therefore, studies on language planning and policy have placed increasing emphasis on the interrelationship between language policy and questions of power. More recently, CDA practitioners have also started to engage with the notion of language ideology. Nevertheless, in recent years, scholars such as AbuLughod (1975 in Ricento and Hornberger 1996: 407) have criticised the 'historicalstructuralist' approach for being too deterministic and disregarding the ability of individuals and the collective to challenge the interests and ideologies of the dominant. This has led to a greater focus on the agency of local actors and the role that individuals and communities play in influencing language policies and resisting and undermining dominant groups and language policies (Tollefson 2013: 26-27; Ricento and Hornberger 1996). 
This development has led to tensions within the field of language policy regarding the importance of structure and agency (Johnson and Ricento 2015: 43). Advocates of the 'historical-structuralist' approach argue that, while power seemingly lies with the dominant, the approach is flexible and assumes that individuals and the collective are also able to challenge and resist dominant structures, ideologies and exploitation (Ricento and Hornberger 1996: 407).

While the 'historical-structuralist' approach has recently been criticised, it is clear that it facilitates an exploration of the way in which power relationships, discourse and politics impacts on policy-processes. The article, therefore, adopts a critical approach to language policy that addresses the role of power and discourse, while also focussing on the agency of language policy actors and their ability to challenge dominant discourses. Combining both complementary approaches allows for a better appreciation of the relationship between structure and agency.

This next section applies this theoretical framework to empirical analysis. It begins by providing a brief overview of the current sociolinguistic context in Wales and the history of in-migration before building on the theoretical framework to develop a greater understanding of the interrelationship between language policy and discursive events in Wales.

\section{In-migration and the sociolinguistic situation in Wales in context}

During the 1960s, the phenomenon of counter-urbanisation prompted many people to move from England to rural Wales. This trend had a significant impact on the sustainability of the Welsh language in rural north-west Wales where it was the majority language. ${ }^{9}$ While the number of newcomers was initially low enough that they were assimilated naturally into the Welsh language communities (Osmond $1992,2)$, the increase in the rate of in-migrants moving to rural Wales during the 1970s and 1980s meant that it became increasingly difficult for these traditional Welsh-speaking communities to remain strongholds in the face of the influence of the English language (Aitchison and Carter 2000a, b). During the same period, the phenomenon of second home tourism also emerged. This type of in-migration, which peaked significantly during the 1980 s, led to the deterioration of rural communities; young couples out-migrated as they were unable to afford house prices, local schools closed owing to the lack of children, and public services were reduced (Davies 2007, 650). Between 1981 and 1990 approximately 600, 000 people chose to settle in Wales, the vast majority moving from other parts of the UK (Osmond 1992). The out-migration of Welsh-speakers further emphasised the presence and impact of non-Welsh speakers (Aitchison and Carter 1991, 71).

In-migration to Wales from the rest of the UK has continued into the twenty-first century, with movement from England accounting for the majority of cross-border migration to Wales. Between 1999 and 2011, there was a net inflow of in-migrants

\footnotetext{
9 The phenomenon of in-migration to Wales is not a new one; the in-migration of English workers and their families during the Welsh Industrial Revolution was one of the main causes of decline in Welsh speakers. See Jenkins (1999) and Jenkins and Williams (2000) for further detail.
} 
from the rest of the UK. Between mid-2007 and mid-2011, north Wales experienced the largest average annual net inflow of in-migrants from England for each age group, apart from the 16-24 age group. Conwy (a county in north Wales) experienced the largest average of number of annual net migrants (an inflow of 2760 and an outflow of 2300) and Gwynedd (a county in north-west Wales) had the largest average annual inflow and outflow rate (3539 in-migrating and 3150 outmigrating) (Welsh Government 2013: 5-8).

The results of the 2011 Census raised many concerns regarding the future of the Welsh language. On a Wales-wide level, there was a decrease in the percentage claiming to be able to speak the language, with the percentage falling from $20.8 \%$ in 2001 to $19.0 \%$ in 2011. There was also a decrease in the number of speakers in the areas where there has traditionally been a high density of Welsh language speakers, with the Welsh language representing a majority language in only two local authorities, Gwynedd (65.4\%) and Anglesey (57.2\%). Both local authorities are in north-west Wales. Furthermore, while $9 \%$ of people born outside of Wales claimed to be able to speak the Welsh language in 2001, the corresponding percentage in 2011 was $8 \%$. In the same manner, a fall was witnessed in the percentage of people born in Wales who could speak the language; from $24.7 \%$ in 2001 to $23.3 \%$ in 2011 (Office for National Statistics 2012). ${ }^{10}$ In 2012, the Welsh Language Board stated that there was a net loss of Welsh speakers on an annual basis and claimed that in-migration, along with out-migration, was one of the main causes of this decrease (Jones 2012, 112).

\section{Party politics, political ideologies and the Welsh language}

Since Welsh devolution in 1997 and the establishment of the National Assembly for Wales in 1999, a degree of political consensus has emerged in Wales regarding the need to safeguard and promote the Welsh language and Welsh-medium education. Prior to this, the Welsh language and Welsh-medium education were the cause of much political and social tension during the twentieth century. Such tensions were often linked to conflicts in party ideology and politics, notably between Plaid Cymru (the Party of Wales) and the Labour Party, which was Wales' dominant party throughout the twentieth century (Scully 2013). As Williams states:

the greatest opposition to the development of Welsh-medium education and of language issues generally came from within Labour-affiliated ranks. The Labour Party was rooted in a British sense of identity, predicated upon social class divisions not ethnic antagonism, and saw any increase in the development of Welsh-medium education as necessarily weakening the British base in favour of a more focused Welsh national (if not necessarily nationalist) identification (2000: 23).

\footnotetext{
${ }^{10}$ However, a slight increase was witnessed in Welsh speakers in two age groups; 3-4 age group and 20-44 age group (Office for National Statistics 2012).
} 
When bilingual schools were formed during the post-war years they were judged for being linguistically and educationally divisive and for serving the interests of a small cultural nationalist elite. Two main arguments were often articulated: first, that bilingual schools 'ran counter to the educational status quo and were an intrusive and additional element within the educational system'. Second, that the 'the most vociferous champions of Welsh-medium schools were key figures with the Welsh-speaking intelligentsia, often, but not necessarily, adherents of Plaid Cymru' (Jones and Williams 2000: 138). Despite the fact that both the Labour Party and Plaid Cymru advocated socialist policies, they were based on different constitutional visions for Wales and Britain; Plaid Cymru represented the Welsh nationalist voice in Wales and the Labour Party was traditionally very centralist.

The passing of the 1993 Welsh Language Act and the establishment of the Welsh Language Board represented two key developments in the depoliticization of the Welsh language issue (Williams 1998: 102). This was followed by the establishment of the National Assembly of Wales in 1999, which led the unionist parties in Wales to adopt more distinct Welsh political agendas and programmes (Elias 2009: 70). Its establishment also symbolised a nascent era in the development of a bilingual society in Wales (Williams 2000: 33).

In 2003, following a period of intense consultation, the Welsh Labour and Welsh Liberal Democrats coalition government published 'Iaith Pawb: A National Action Plan for a Bilingual Wales'. The language strategy set out how the Welsh Government intended to achieve the goal of revitalising the Welsh language and creating a bilingual Wales. This was the first time that cross-party political support and a shared vision for the Welsh language had been voiced through the medium of a Wales-wide action plan (Williams 2005: 1-2). In 2007, the Welsh Labour Party and Plaid Cymru coalition government endorsed 'One Wales-A Progressive Agenda for the Government of Wales'. The coalition agreement showed a clear commitment to safeguarding the future of the Welsh language and included several proposals to achieve this objective (Welsh Government 2007: 22-36).

Whilst the coalition was based on the Welsh Labour Party accepting these language measures, which were largely Plaid Cymru contributions, the fact that an agreement was reached suggests that there was not enough objection on Welsh Labour's behalf to such legislative and policy developments in the fields of Welsh language and Welsh-medium education. This accord also reflects the way in which the legislative and policy fields of Welsh language and bilingual education have developed over the decades. ${ }^{11}$ The 'One Wales' agreement also set the basis for further legislative and policy developments in the field of language policy such as the Welsh-Medium Education Strategy (2010), the Welsh Language (Wales) Measure (2011) and the new Welsh language strategy, 'Iaith Fyw: Iaith Byw' (A Living Language: A Language for Living) (2012). ${ }^{12}$

\footnotetext{
11 In addition, in 2003, the Welsh Language Board and the Equality and Human Rights Commission issued a protocol for the four main parties in Wales. By signing this symbolic contract, the political parties agreed not to abuse free speech or initiate, create or exploit prejudices about the Welsh language, whether overt or covert, in the political competition for votes (Welsh Language Board 2003).

12 The Welsh Language (Wales) Measure 2011 established a new legislative framework for the Welsh language and gave the Welsh language official status in Wales. It also established a Welsh Language
} 


\section{Discursive debates and struggles on in-migration and the Welsh language}

Despite the fact that there now exists a 'form of settled consensus' on the Welsh language (Loughlin 2007: 47), a similar agreement has not been reached regarding the subject of in-migration and its impact on the Welsh language. Over the years, efforts to discuss in-migration have resulted in controversy with debates resulting in discourses of racism, nationalism and xenophobia. There are several examples of this but two cases will be discussed here to highlight the nature of the discussion since Meredydd Evans' speech in 1986.

In 2001, the subject of in-migration became a topic of controversy, following the remarks made by a Plaid Cymru councillor from Gwynedd during a BBC radio Wales interview. In referring to the impact of in-migration to a predominantly Welsh speaking community in north-west Wales, Seimon Glyn, Plaid Cymru Chair of Gwynedd's Housing Committee stated:

We're faced with a situation now where we are getting tidal waves of migration, inward migration into our rural areas from England and these people are coming to live, to establish themselves here and to influence our communities and our culture with their own... Now if they were coming here under strict monitoring and control and if, for example, they were made aware of you know the different cultural aspects of these areas and made to or be persuaded to learn Welsh and to integrate smoothly into our communities there wouldn't be a problem (in Brooks 2006: 147).

In the days following the interview, the Welsh and UK tabloid press demonized Seimon Glyn for his remarks and denounced him as a racist-nationalist. His comments were likened to a "racist" rant' and several members of the Labour Party, including the then Labour Party Prime Minister, Tony Blair, and Secretary of State for Wales, Paul Murphy, condemned Seimon Glyn and Plaid Cymru for the nature of the comments (Brooks 2006). Members of the Labour Party called upon Ieuan Wyn Jones, then leader of Plaid Cymru, to expel Seimon Glyn from the party, despite the fact that the Labour Party was taking part in discussions on British citizenship and English language requirements for international immigrants to Britain during the same period (ibid.).

Nevertheless, the controversy did not end with the publicization of Seimon Glyn's interview; it evolved and became a very public political debate between Plaid Cymru, the Labour Party and the tabloid press. This period witnessed the reemergence of party politics, ideologies and tensions based on the Welsh language. While Plaid Cymru had focussed on ridding itself of the image of being the party for Welsh-language speakers, mainly based in north-west Wales, and widening its appeal to new voters, the debate brought to the fore old criticisms and critiques. By

Footnote 12 continued

Commissioner and an Office of Welsh Language Commissioner to take up the new legislative competencies, and led to the abolishment of the Welsh Language Board (Welsh Language (Wales) Measure 2011). 
using terms that reverberate with the rhetoric of overtly anti-immigrant and rightwing extremist parties, such as 'tidal waves' and 'monitoring', Seimon Glyn made it easy for Labour politicians to link the Welsh language with Welsh nationalism and racism. This reinforced the concept of 'racist-nationalist', a long-established critique of Plaid Cymru by Labour politicians (Wyn Jones 2014). One such example is that of Don Touhig, Labour MP, who declared that Seimon Glyn's 'disturbing comments reveal the dark underbelly of Welsh nationalism' (Welsh Mirror 2001a: $1-2)$.

For Loughlin, the Labour Party 'was eager to portray the comments as an example of racism against the English rather than address language planning issues in the Welsh heartlands' (2007: 47). Brooks (2006: 139) and Wyn Jones (2014: 21-22) advance that the response of the Labour Party in Wales was part of a wider political strategy to damage Plaid Cymru at a time when they appeared to be challenging Labour's long-standing hegemony in Wales. Whilst Plaid Cymru's support had traditionally been limited to rural Wales, especially the Welsh speaking north-west, Plaid Cymru's success in the first National Assembly for Wales elections in 1999 represented a 'quiet earthquake' (Trystan et al. 2003). It saw Plaid Cymru's best ever election performance by far with the party winning traditional heartland Labour seats (Trystan et al. 2003; Wyn Jones and Trystan 2000). By drawing parallels between nationalism, racism and in-migration, some Welsh Labour politicians sought to undermine the ability of Plaid Cymru to represent nonWelsh speaking electorates (Brooks 2006) and exclude the party 'from the midst of political discussion in Wales' (Wyn Jones 2014: 73). The debate, thus, represents a discursive struggle that led to Plaid Cymru being undermined as a political party.

The tabloid press also played an important role in the development of the debate. According to Wyn Jones (2014: 21-22), the tabloid Welsh Mirror, which was established in 1999 'in an attempt to steady and restore the fortunes of the Labour Party in Wales', actively portrayed Plaid Cymru and Welsh nationalism as being synonymous with Fascism. By the time the Welsh Mirror ceased publication following the May 2003 election, Plaid Cymru had suffered as a result of being branded as a party tainted by Fascism and the Labour Party, having rebranded as 'Welsh Labour', had successfully reconnected with the Welsh electorate (ibid.). The involvement of the Welsh Mirror in the production and reproduction of discourse highlights how access to the media is a valuable resource for actors.

The debate on in-migration prompted the formation of the pressure group, Cymuned ('Community') in 2001. It described itself as an anti-racist organisation which opposed, not in-migration itself, but that form of in-migration which could be perceived as colonization (Davies 2007, 689). Its objective was to campaign on behalf of Welsh speaking and rural communities perceived as being under pressure due to demographic change and engage in constitutional lobbying. Its policies included controlling in-migration into Welsh-speaking areas, curb out-migration, linguistically assimilating newcomers and establishing the Welsh language as the primary language in Welsh-speaking areas (Royles 2007: 86). Despite these intentions, Cymuned struggled to engage in lobbying and policy-making. One of the main causes for this was that certain Labour politicians and the tabloid press viewed the organisation as being inherently racist: 
The Welsh Mirror had a hate campaign against us, which was stressful. The police were keeping tabs on us, which was stressful, you know? There were constant accusations that we were inciting racial hatred, which was stressful (own translation, Cymuned, Interview 2, 2011).

This contentious environment was particularly evident during the Culture Committee's Policy Review of the Welsh Language that took place between May 2001 and March 2002 (Royles 2007: 91). ${ }^{13}$ On the morning of Cymuned's presentation, the Welsh Mirror printed a front page exclusive, claiming that two Labour AMs, Lorraine Barrett and Huw Lewis, intended to 'ask the Home Office for a ruling on whether the proposals constitute a breach of new race-hate laws'. Lewis likened Cymuned's proposals to 'language apartheid' and Barrett added that the ideas were dangerous and divisive and bordered on fanaticism (Welsh Mirror 2001b: 1).

Cymuned's efforts to influence policy were met with hostility, with some Labour Party politicians accusing the pressure group of being 'extremist' and a racist movement. This reaction also highlighted that a faction within the Labour Party still held negative views towards the Welsh language (Royles 2007: 95). Plaid Cymru politicians also viewed the newly-founded pressure group with suspicion as Cymuned had failed to make it clear that they were not forming as a political party (ibid. 94).

For a Welsh Labour Party politician, however, the main reason for the controversy surrounding Seimon Glyn's radio interview and Cymuned's lobbying efforts was the provocative nature of the approach:

It seems to me that it appeared to have been raised in an inflammatory way, rather than in a constructive way. You have to then say that, well, the climate around the Welsh language, some of the divisions around that were probably sharper then and some of the journalists involved in the debates may have more of an axe to grind then (Welsh Labour Party AM, Interview 19, 2012).

For Brooks, Cymuned's failings can be attributed to two factors: the tensions between the Labour Party and Plaid Cymru, and the influence of the British discourse on the discussion in Wales. Regardless of the aim or source of the debate, within a British context, discussions regarding the impact of in-migration on the Welsh language will inevitably be linked to race (2006, 144). While Blommaert states that debates represent a point of entrance for civil society into policy-making and are historical moments during which the polity gets involved in influencing policy $(1999,8)$, Cymuned was unable to shape policy in the field. To all extent and purposes, Cymuned has ceased to exist.

Whilst politicians and academics disagree on the reason for the sensitivities surrounding the topic, it is clear that no political party in Wales has taken ownership of the debate on in-migration:

...The truth is that Plaid Cymru, like every other party, has danced around the subject to some extent. Partly because the difficulty of doing anything about

\footnotetext{
13 See Royles (2007: 85-103) for more on Cymuned's role and influence on policy development.
} 
the issue...I don't think that Wales has the power to do anything even if you wanted to do anything. But, it has been such an emotive subject and so... The truth about it is that, politically, all parties have avoided the issue... If you are going to legislate in this field, you need political support, otherwise, it won't happen (own translation, Plaid Cymru AM, Interview 13, 2011).

Therefore, while Plaid Cymru is often perceived as being the party representing Welsh-speakers in Wales and defending the Welsh language and culture, the wider discourse surrounding the subject of in-migration has led to the party's unwillingness to broach the subject:

Plaid Cymru doesn't want this discussion, because they are fearful that they would lose seats by holding this discussion. So, you've got this political element of not wanting to tackle this issue on a national level (own translation, Welsh Language Board, Interview 5, 2011).

The subject of in-migration, therefore, has raised significant tensions between politicians, journalists and civil society actors to the extent that there is a reluctance to deal with the issue.

However, this hesitancy extends to the wider political process of policy-making. Interviews conducted with policy-makers confirmed that, similar to politicians, they too have been reluctant to approach the subject. While there is a consensus amongst those working to promote and revitalise the Welsh language that in-migration undermines the sustainability of the Welsh language, there has also been a general hesitancy to discuss the subject openly for fear of ramifications. Even the Welsh Language Board, the main body responsible for language planning in Wales until its dissolution in 2012 was reluctant to discuss the subject publicly:

It would have blown us out of the water if we'd tried to get a substantive policy or lobby for a substantive policy. It is considered as racism. Yes. Less so by now, but it was perceived as an issue that was based on racism and antiEnglishness more than anything else (own translation, Welsh Language Board, Interview 5, 2011).

The reluctance to discuss the issue openly was made all the more difficult following remarks made by its former Chair, John Elfed Jones in 2003. ${ }^{14}$

In consonance with Brooks (2006), policy-makers feel that discussions on inmigration and the Welsh language are formed within a British context and that attempts to influence policy or debates in Wales are made difficult by the wider discourse on in-migration:

What could be making it difficult at the moment is the fact that, as I was saying, there is also a British dialogue or discourse. It is possible that this is more sensitive at times as there are very different racial considerations to the

\footnotetext{
14 In 2001, John Elfed Jones, former Chair of the Welsh Language Board, suggested that in-migration was changing rural life in the same manner as the foot and mouth disease. He added that, whilst the Welsh Government had managed to protect rural life from the disease, it had failed to protect it from the effects of in-migration (BBC 2001).
} 
ones in Wales, and perhaps this makes it difficult to discuss the subject (own translation, Welsh Language Board, Interview 1, 2011).

This was a unifying theme that emerged in a number of interviews with policymakers and practitioners (Welsh Language Board, Interviews 1, 7, 2011). There was also the feeling that, in a British context, in-migration to Wales from England is not considered as migration:

So that [the British context] influences on what's happening in Wales. And what's strange is that often they [Westminster parties] don't think that inmigration between England and Wales is in-migration at all. But of course, for us in Wales, anyone who doesn't perhaps speak Welsh is in-migrating, it doesn't matter who they are. Whether they are from England or abroad, they are the same. [...] Because we reacted to the Polish that moved to Ceredigion in the same way as we reacted to the non-Welsh speaking English people that moved there (Welsh Language Board, Interview 7, 2011).

While policy-makers and practitioners consider population movement to Wales from other parts of the UK as in-migration, this is not necessarily accepted within a wider British context where the emphasis is on international immigration.

In addition, unlike Welsh language politics, which is less emotive than it was 30 years ago, it is clear that in-migration remains an arena of conflict in language policy:

The subject of in-migration has not developed [since devolution] to the same extent as the field of language policy [...] And it isn't possible to have a balanced discussion, publicly about it yet, I don't think (own translation, Welsh Language Board, Interview 6, 2011).

Thus, political climate and support continues to play a significant role in shaping language policy in Wales:

In reality, the political climate is fundamental. That is, after all, it is political individuals that are responsible for policy, in the end. It doesn't matter how much advice they receive from civil servants and so on [...] It is the political climate that then determines the national direction of a national strategy (own translation, Welsh Language Board, Interview 1, 2011).

Furthermore, whilst the Welsh Language Board worked at arm's length from the Welsh Government, it was nevertheless a government-funded body that relied on political will to achieve its aims and objectives. In the absence of open political support on the subject of in-migration, the language planning body felt it was unable to implement an ambitious and cohesive strategy dealing specifically with inmigration:

So, the Board has to be quite careful, because there is no support available [...] At the end of the day, having a strategy for dealing with migration is a political decision. So, it has to go to the politicians (own translation, Welsh Language Board, Interview 5, 2011). 
This reveals how the policy process in the field of in-migration remains 'political' and demonstrates how policies often serve political goals that emerge in response to important social forces such as political conflicts or tensions (Luke et al. 1991, 34; Tollefson 2002, 327; Paulston 1992, 80).

The study also reveals the existence of a second discourse on in-migration, albeit on a more micro level. This discourse, which is based on Welsh language sustainability, acknowledges that in-migration undermines the future of the language. However, the explosive nature of the more mainstream discourse on inmigration, which is linked to racism, means that policy-makers have not been able to develop discussions linking in-migration to language sustainability. This is exacerbated by the fact that Welsh language civil society organisations such as Cymdeithas yr Iaith Gymraeg, which campaigns for the right of Welsh people to use the Welsh language in every aspect of their lives, and Cymuned do not have the capacity to intervene as pressure groups. Consequently, these debates regarding inmigration are largely confined to the Welsh-speaking realm. This alternative discourse is thus produced and reproduced within restricted Welsh language policy networks and communities.

These discussions remain further isolated as the language question remains unimportant to civil society organisations in Wales that are not specifically based on promoting and safeguarding the Welsh culture and language. Apart from Welsh language and cultural organisations, there is a lack of authoritative voices that are able to promote discussions on matters involving language and in-migration. Discussions linking in-migration to language sustainability have not been articulated and the marginalized position of these pressure groups means that they have failed to influence the wider discourse on in-migration that has gained prominence on a Welsh and British level. This is also true of discussions that are articulated in the Welsh-language media. At different points in the Welsh Language Board's lifetime, the Chief Executive and Chair of the organisation stated that in-migration was one of the greatest challenges facing the Welsh language (Huws 2007: 26; Jones 2011: 6). Nevertheless, these statements were printed in Welsh-language magazines and contributed towards empirical discussions and normative viewpoints that had already been largely accepted by the Welsh-speaking audience and media.

Analysis of policy plans and strategies alongside the interviews revealed that the political climate surrounding the subject of in-migration led policy actors to adopt alternative approaches to deal with the phenomenon. The Welsh Language Board, working in partnership with a number of partners, concentrated its efforts on strengthening communities where $70 \%$ of the population spoke Welsh. By striving to empower and support the existing Welsh speakers in these communities through a number of projects, the aim was to arrest out-migration and ensure that the communities were less vulnerable to the phenomenon of in-migration:

But maybe we've tried to approach it by trying to empower the Welshspeaking Welsh rather than trying to deal with in-migrants. And I think that that has been a conscious policy of ours. That we've realised that in-migration is beyond our ability, more than dealing with the fringes. [...] So what we've tried to do in this vacuum, in this policy vacuum, and because of the problems 
regarding the feelings that we are being racist, we do what we are able to, which is to empower the Welsh-speaking Welsh (own translation, Welsh Language Board, Interview 5, 2011).

This link between linguistic, economic and community sustainability is a theme that can be traced to the campaigns of Cymdeithas yr Iaith Gymraeg and Cymuned (Cymdeithas yr Iaith Gymraeg 1999: 15, 2013; Cymuned 2001: 9). The Welsh Government has also stressed the relationship between in-migration, out-migration and linguistic, social or economic sustainability (2003: 6, 33-35, 2012: 34).

Undertaking a diachronic analysis of the discursive struggles on in-migration has facilitated a greater understanding of the nature of discourses on in-migration and how different categories of actors have been able to construct, influence upon and articulate discourse. Studying Meredydd Evans' speech in 1986, Seimon Glyn's radio interview in 2001 and Cymuned's lobbying efforts between 2001 and 2003 has highlighted several common themes, notably that of power structures and unequal access to the production and reproduction of discourse. This may not have come to the fore during a synchronic study. The study reveals that the subject of inmigration is an arena of discursive conflict and within this field certain politicians and political groups have a greater voice and influence over the development of such discourses. While Plaid Cymru has traditionally represented the voice of Welsh-speakers, it faced significant criticism and subsequently, distanced itself from the issue. In the same manner, policy-makers and proponents of the Welsh language were also reluctant to broach the subject.

Certain Labour Party politicians, however, represented the discourse 'brokers' (Blommaert 1999: 9) and claimed greater authority in the field. They were also able to reproduce a discourse linked to nationalism and racism through the Welsh Mirror's widely-circulated, complementary, and consistently promoted discourse. The involvement of the Welsh Mirror along with other media outlets in the (re)production of discourse highlights the connection between discourse, media and politics along with the hidden power of the media (Fairclough 1989: 43). While the study revealed the existence of two juxtaposing discourses on in-migration; that of the one based on racism, intolerance and nationalism and, that of the one based on language sustainability, the tabloid press facilitated actors in making the former more mainstream. The latter discourse is restricted to the local or community level and exists within Welsh language communities, policy networks and Welshlanguage media.

Analysing the real actors and studying debates and discursive events in a diachronic manner reveals how discourse is in itself seen as a crucial symbolic resource onto which people project their interests, around which they can construct alliances, on and through which they exercise power' (Blommaert 1999: 7). The outcomes of debates on in-migration, therefore, are indicative of the wider power structures at play and reveal how conflict and inequality are part of the political process. While it is not possible to claim that one particular individual or group has had complete control over the development of discourse, the study showed that some individuals or groups have had greater ability to influence political debates. This unequal access to discourse means that there have been clear 'winners' and 
'losers'; with the mainstream discourse on in-migration eclipsing the communitybased discourse on language sustainability. Those who advocate the need to react to in-migration and ensure language sustainability have, on the whole, failed to have their fears and frustrations heard. The discussion also revealed how language policy actors have attempted to resist certain power structures by adopting creative and unexpected approaches to the phenomenon of in-migration.

\section{In-migration projects}

This next section explores how such debates and discursive struggles impact on policy in the field and outlines a number of in-migration projects. It focusses on the area of north-west Wales to gain a better understanding of language policy processes on a micro level and to exemplify the impact of discourse on a Waleswide level on policy.

Despite the reluctance within the Welsh Language Board to deal with inmigration directly, in-migration is stated in 'Iaith Pawb' (Welsh Government 2003) as representing one of the main causes in the decline of Welsh-speaking communities over recent years. The action plan refers to the impact of in-migration and out-migration on the sustainability of the Welsh language (ibid. 21) and situates both phenomena within wider issues such as economic change and social dislocation:

In recent decades, the demographic trends in Welsh-speaking areas have been for young people to leave, to be replaced, if at all, by the in-migration of older, non-Welsh speakers. These trends have an adverse effect on the social and economic balance of the community and there are serious associated implications for the Welsh language, since the young leavers take with them the future of the language in those areas (ibid. 32).

Nevertheless, the language strategy does not articulate a specific policy that aims to integrate adult in-migrants into the Welsh-language community. Instead, the main measure outlined in 'Iaith Pawb' is the 'Welcome Packs' project, which was stated a means 'to increase the opportunities for newcomers and non Welsh-speaking adults in Welsh-speaking areas to learn the language, so they can fully participate in all aspects of life in their new community and contribute to supporting and sustaining one of the most distinctive features of that community' (ibid. 34). In this respect, there is a clear disconnection between the emphasis placed on the effects of inmigration in the language strategy and the measures put in place to deal specifically with the integration of in-migrants. ${ }^{15}$

In addition to the 'Welcome Packs' project, a number of additional projects were designed and implemented in order to encourage in-migrants to integrate into the Welsh language community. These projects were successful in many ways; they led

\footnotetext{
15 Whilst 'Iaith Pawb' (2003: 46) discusses the importance of learning Welsh as a second language and the significant role that the 'Welsh for Adults' Centres play, this provision does not differentiate between in-migrants and non-Welsh speaking Welsh persons.
} 
to an increased awareness amongst in-migrants of the Welsh language and culture, sensitised local Welsh speakers regarding the needs of in-migrants and facilitated collaboration between a number of local and national actors (Canfod 2007; Hywel Evans Cyf 2009: 3-5). The socio-linguistic context in Wales also meant that implementing policy on a micro level facilitated actors in establishing necessary contacts and responding to local needs. ${ }^{16}$

However, these projects, which were reactionary and ad-hoc, also reveal how the field of in-migrant integration was characterised by a lack of co-ordinated, longterm planning. In addition, whilst the number of partners involved in projects reflects the commitment on a local level, it also led to a duplication of efforts (North Wales Welsh for Adults Centre, Interview 9, 2012). This provides further evidence of the disconnection between stated 'policy' and practice. Indeed, the sensitive nature of the subject meant that policy-makers on a Wales-wide level felt unable to design continuous and ambitious projects to deal with the phenomenon. This situation led to a feeling of frustration and powerlessness amongst policy-makers who wished to implement further measures to integrate in-migrants (Welsh Government, Interview 3, 2012; Welsh Language Board Interviews 1, 5, 6, 7, 2011). A few of these projects are discussed below.

In 2001-2002, the Welsh Government financed the Welsh Language Board to establish specific in-migration projects, which included creating a website and associated publicity material for the pilot 'Welcome Packs' project. The packs provided information on the educational and linguistic context in the local area, a list of 'Welsh for Adult' providers, basic information about community life and suggestions regarding opportunities available to use the Welsh language. The packs were distributed through a partnership with local estate agents, local authorities, housing associations and a consortium of 'Welsh for Adults' providers. In 2005-2006, the Welsh Language Board commissioned a study on the language packs. The findings revealed that despite agreeing to distribute the packs, only one of the 133 estate agents contacted sent out a 'Welcome Pack' to a potential buyer (Utgorn 2006). As the Welsh Language Board was unable to require estate agents to circulate the packs, the project's success was dependent on the goodwill of local organisations and businesses. The funding allocated to establishing a website was also too small and meant that the initial objectives and aims of the website could not be achieved (Welsh Language Board, Interview 20, 2011). ${ }^{17}$ Therefore, while inmigration is stated as representing one of the greatest challenges facing the Welsh language in 'Iaith Pawb', the projects formulated to deal specifically with inmigrant integration do not reflect its scale.

In addition to the 'Welcome Packs', the Welsh Language Board also worked in partnership with the 'Mentrau Iaith' (Language Initiatives) to implement projects on a community level to integrate in-migrants, mainly in north-west Wales (Welsh

\footnotetext{
16 As outlined in 'Iaith Pawb', using local structures through local action plans is a means 'to increase and encourage awareness, visibility and use of the Welsh language in economic, social and cultural situations at the local level' that also reflects 'local circumstances and needs' $(2003,30)$.

17 Instead, the Welsh Language Board worked with BBC Wales to create a page on the Living Wales section of the BBC Wales website: http://www.bbc.co.uk/wales/livinginwales/.
} 
Language Board 2005: 20). ${ }^{18}$ With Gwynedd Council and Gwynedd's local language initiative, 'Hunaniaith', the Welsh Language Board created a project to encourage in-migrants that had moved to the local area to integrate into the Welsh language community. They were provided with information regarding community life, the Welsh language and 'Welsh for Adults' courses, and were encouraged to attend cultural activities. Findings of a research undertaken by Canfod in 2007 revealed that, generally, in-migrants appreciated the aim of the scheme, but there existed a certain amount of apathy amongst the Welsh-speaking locals towards inmigrants. ${ }^{19}$ In its findings, Canfod emphasised the need to develop the scheme further, focus on educating local Welsh speakers, and create additional networks to support in-migrants to learn and use the language. The Welsh Language Board terminated the project after a few years as it was failing to fulfil its full potential and because of financial constraints (Canfod 2007; Welsh Language Board 2006, Welsh Language Board, Interview 20, 2011).

In 2008, 'Hunaniaith', the Welsh Language Board and the North Wales Welsh for Adults Centre collaborated on a Welsh Language Board-funded project. The project provided language and culture awareness sessions to in-migrant families with the aim of facilitating and encouraging their integration into the Welsh language community. It also emphasised the crucial role that parents play in supporting their children's learning in Welsh-medium or bilingual education. The pilot project was held in the Language Centre for Latecomers in Caernarfon and offered five starter sessions to newcomer parents on topics such as the Welsh language, culture, history and local produce. ${ }^{20}$ Whilst it was considered a success by the Welsh Language Board, and it was rolled out to other rural areas in Wales, it was nevertheless a micro project involving a small number of participants and with a limited budget (Welsh Language Board, Interview 20, 2011).

Between 2006 and 2009, the Welsh Language Board put in place another project to facilitate in-migrant integration. The aim of the scheme, which brought together Menter Iaith Môn, the local initiative on Anglesey, and the local Language Centre for Latecomers, was to create opportunities for in-migrants to be part of the local community. This was to be achieved through activities and social events that raised awareness of the Welsh language and culture and promoted 'Welsh for Adults' classes. Over the course of 3 years, over 207 people participated in the scheme. This led to the North Wales Welsh for Adults Centre organising additional classes in Anglesey (Hywel Evans Cyf 2009: 3-5).

Therefore, one of the most tangible manifestations of the role that discourse and politics play is the conflict between policy and practice in the field of in-migrant

\footnotetext{
18 A 'Language Initiative' is a community-based organisation that works to raise the profile of the Welsh language in a specific area by working with individuals, organisations, and local business.

19 For more on the attitudes of English in-migrants to north Wales, see Davis et al. (2010, 148-167).

20 In 1984, Gwynedd Council opened the first 'Language Centre for Latecomers' in Caernarfon, which was also the first of its kind in Wales. The aim of the centres was to integrate non Welsh-speaking pupils between the ages of 7 and 11 into the Welsh language for a period before they were able to attend the Welsh-medium community primary schools. They had a teacher-pupil ratio of $1: 10$. These centres continue to play an important role in the linguistic integration of non Welsh-speaking pupils in areas where a high proportion of the population speaks Welsh (Welsh Government 2003: 41-42).
} 
integration. While in-migration is acknowledged as one of the main challenges facing the Welsh language, the projects designed to encourage in-migrants to integrate linguistically do not reflect the scale of this challenge. This section, therefore, reveals the extent to which political ideology 'drives policy in particular directions, creating various divergences between stated policy and actual practices' (Romaine 2002: 204). The divergence is such that no clear, uniform policy was adopted. Instead, rather than a 'policy', the Welsh Government and Welsh Language Board tackled in-migration with measures that could be described as being more piecemeal. In addition, the voluntary, rather than mainstream nature of the projects and the fact that this only involves a small number of learners suggests that efforts to limit the negative effects of in-migration on the vitality of the Welshlanguage can be described as 'tolerance-oriented' policies (Wiley 2013) as opposed to 'promotional' policies (Kloss 1998). In the field of in-migrant linguistic integration, there has been a noticeable lack of intervention on behalf of the Welsh Government.

\section{Conclusion}

The empirical case study presented in this article has highlighted the need for research methods in the field of language policy to adopt an approach to language policy that reflects dimensions of the 'historical-structuralist' approach while also giving full consideration to the agency of actors involved in language policy processes. Despite the current trend in the scholarship to focus on the grass-roots level and the role and efforts of language agents in resisting top-down language policy, it remains that adequate attention must also be given to wider historical and structural processes in language policy processes. The study also highlights a theme that is relevant to minority language communities beyond Wales: that of the relationship between policy, politics and power relations. It is clear that neither language nor policy is ever neutral, they are very much bound up in wider power structures. This confirms that language groups should not be conceptualised in terms of their numerical or empirical dimensions, but rather in terms power, status or authority (Nelde et al. 1996: 1; Skutnabb-Kansas 1990).

In addition, the article has led to several key findings on the interrelationship between discourse, politics and Welsh language policy in the field of in-migration. They can be summarised as; a greater understanding of the discursive and ideological traditions in the field of Welsh language politics; uncovering certain power relationships, structures and hierarchies, and highlighting the political factors at work during policy development, implementation and formulation.

The analysis of discursive debates also highlights the differing extent to which actors are able to produce, reproduce and contribute to discourse. This shows that certain groups and individuals have more power over discourse than others (Jager and Maier 2009: 37-39), that power can be 'in' or 'behind' discourse, and that the nature of the power relations in mass media is 'hidden' (Fairclough 1989: 43). The fact that the Welsh Mirror and the Welsh Labour Party shared complementary discourses meant that the Welsh Labour Party had greater ability to influence 
discourse and a more privileged access to the media. Other actors, however, were not as powerful in creating or articulating their discourse and were effectively excluded from discussions and policy-making processes in the field of in-migration. The fears and frustrations of those attempting to articulate a discourse based on linguistic sustainability went unheard despite efforts to encourage an open and mature debate on in-migration. In this respect, both the subject of in-migration and the actors working in the field of Welsh language policy have been 'depoliticised'; they have been excluded from 'processes of political deliberation and decision' and have been 'placed outside politics' (Fairclough 2009: 173). While Blommaert $(1999,8)$ advances that debates represent a point of entrance for civil society into policy-making and are perceived as historical moments during which the polity is involved in influencing policy, analysis of debates on in-migration reveal that Cymuned failed to shape policy in the field. To a certain extent, these debates are 'inconsequential' as they have failed in terms of 'power effects' and outcomes (ibid. $10)$.

The findings of the study are also illustrative of the wider field of language policy and planning in Wales. While the Welsh-language has official status in Wales as set out in the Welsh Language (Wales) Measure 2011, and consequently has governmental support in a range of public sector domains, policy-makers and practitioners are faced with a situation where they have to formulate and implement measures without upsetting the political equilibrium. This interrelationship between policy and politics highlights the importance of adopting an approach to language policy that takes into account the 'real social actors'. Therefore, to understand the limitations and challenges facing policy-makers as they attempt to formulate and implement policies to support and revitalise minority language communities, adequate attention must be given to the wider political context in academic analyses. Language policy-makers should also be made aware of the fact that power is an integral aspect of language policy and planning.

Acknowledgments I would like to thank the three anonymous referees for their insightful comments and suggestions. I would also like to thank colleagues at the School of Political studies at University of Ottawa and the Department of International Politics at Aberystwyth University for providing useful feedback on early drafts. An early version of this article was also presented at the 2014 IPSA Congress in Montreal.

Open Access This article is distributed under the terms of the Creative Commons Attribution 4.0 International License (http://creativecommons.org/licenses/by/4.0/), which permits unrestricted use, distribution, and reproduction in any medium, provided you give appropriate credit to the original author(s) and the source, provide a link to the Creative Commons license, and indicate if changes were made.

\section{References}

Aitchison, J. W., \& Carter, H. (1991). Rural Wales and the Welsh language. Rural History, Economy, Society and Culture, 1(2), 61-79.

Aitchison, J. W., \& Carter, H. (2000a). Yr Iaith Gymraeg 1921-1991: Perspectif Geo-Ieithyddol. In G. H. Jenkins \& M. A. Williams (Eds.), 'Eu Hiaith a Gadwant'? Y Gymraeg yn yr Ugeinfed Ganrif (pp. 27-106). Cardiff: University of Wales Press. 
Aitchison, J. W., \& Carter, H. (2000b). Language, economy and society: The changing fortunes of the Welsh language in the 20th century. Cardiff: University of Wales Press.

BBC. (2001). The man behind the row. http://news.bbc.co.uk/1/hi/wales/1478230.stm. Accessed September 2014.

Blackledge, A. (2005). Discourse and power in a multilingual world. Amsterdam: John Benjamins Publishing Company.

Blommaert, J. (Ed.). (1999). Language ideological debates. Berlin: Mouton de Gruyter Press.

Blommaert, J. (2005). Discourse. A critical introduction. Cambridge: Cambridge University Press.

Blommaert, J., \& Bulcaen, C. (2000). Critical discourse analysis. Annual Review of Anthropology, 29, $447-466$.

Brooks, S. (2006). The idioms of race. In T. Chapman (Ed.), The idiom of dissent: Protest and propaganda in Wales. Gomer: Llandysul.

Canfod. (2007). Ymchwil Cynllun Cymhathu Llŷn. Criccieth: Canfod.

Cymdeithas yr Iaith Gymraeg. (1999). Llawlyfr Deddf Eiddo. Papur Gwaith 2. Tai a Chynllunio yng Nghynulliad Cenedlaethol Cymru. Aberystwyth: Cymdeithas yr Iaith Gymraeg.

Cymdeithas yr Iaith Gymraeg. (2013). A living manifesto for living communities: An action plan for language, work and community. http://cymdeithas.org/sites/default/files/ManiffestoBywCyIG\% 20Medi\%2013\%20Saesneg.pdf. Accessed October 2014.

Cymuned. (2001). Tai, Gwaith ac Iaith. Argymhellion Cymuned i Arolwg y Cynulliad o'r Iaith Gymraeg. Aberystwyth: Y Lolfa.

Davies, J. (2007). Hanes Cymru. London: Penguin.

Davis, H., Day, G., \& Drakakis-Smith, A. (2010). Attitudes to language and bilingualism among English in-migrants to north Wales. In D. Morris (Ed.), Welsh in the twenty-first century. Cardiff: University of Wales Press.

Elias, A. (2009). Minority nationalist parties and european integration: A comparative study. Oxon: Routledge.

Fairclough, N. (1989). Language and power. London: Longman.

Fairclough, N. (2009). A dialectical-relational approach to critical discourse analysis in social research. In R. Wodak \& M. Meyer (Eds.), Methods of critical discourse analysis (2nd ed., pp. 162-186). London: Sage.

Fairclough, N., \& Wodak, R. (1997). Critical discourse analysis. In T. A. van Dijk (Ed.), Discourse as social interaction (pp. 258-284). London: Sage.

Ffrancon, A., \& Jenkins, G. H. (Eds.). (1994). Merêd. Detholiad o Ysgrifau Dr. Meredydd Evans. Llandysul: Gomer.

Hewitt, D. (1986, August 5). Immigrant curb to save Welsh urged. In Western mail (Cardiff). No. 36, 365, p. 1.

Huws, M. (2007). Her y Mewnlifiad. Barn, 532, 26-27.

Hywel Evans Cyf. (2009). Cynllun Cymhathu De-Orllewin Môn - Gwerthusiad. Llanbrynmair: Hywel Evans Cyf.

Jager, S., \& Maier, F. (2009). Theoretical and methodological aspects of foucauldian critical discourse analysis and dispositive analysis. In R. Wodak \& M. Meyer (Eds.), Methods of critical discourse analysis (2nd ed., pp. 34-61). London: Sage.

Jenkins, G. H. (1999). Cymru, Cymry a'r Gymraeg: Rhagymadrodd. In G. H. Jenkins (Ed.), Gwnewch Bopeth yn Gymraeg: Yr Iaith Gymraeg a'i Pheuoedd 1801-1911 (pp. 1-34). Cardiff: University of Wales Press.

Jenkins, G. H., \& Williams, M. A. (2000). Hynt yr Iaith Gymraeg 1900-2000: Rhagymadrodd. In G. H. Jenkins \& M. A. Williams (Eds.), 'Eu Hiaith a Gadwant'? Y Gymraeg yn yr Ugeinfed Ganrif (pp. 1-25). Cardiff: University of Wales Press.

Johnson, D. C., \& Ricento, R. (2015). Methodologies of language policy research. In M. Bigelow \& J. Ennser-Kananen (Eds.), The Routledge handbook of educational linguistics (pp. 38-49). New York: Routledge.

Jones, M. P. (2011, December 1). 'Llywodraeth, nid Comisiynydd, fydd yn achub y Gymraeg'. In Golwg, 24(14), p. 6.

Jones, H. (2012). Darlun Ystadegol o Sefyllfa'r Gymraeg. Cardiff: Welsh Language Board.

Jones, G. E., \& Williams, C. H. (2000). Reactive policy and piecemeal planning: Welsh-medium education in Cardiff. In G. Williams \& D. Morris (Eds.), Language planning and language use: Welsh in a global age. Cardiff: University of Wales Press. 
Kloss, H. (1998). The American bilingual tradition (2nd ed., p. 347). Washington, DC: The Center for Applied Linguistics and Delta Systems.

Loughlin, J. (2007). The Welsh case: Cultural diversity of a nation with devolved powers in a unitary state. In D. M. Smith \& E. Wistrich (Eds.), Regional identity and diversity in Europe: Experience in Wales, Silesia and Flanders (pp. 34-63). London: Federal Trust.

Luke, A., et al. (1991). On the limits of language planning: Class, state and power. In R. B. Baldauf \& A. Luke (Eds.), Language planning and education in Australasia and the South Pacific. Clevedon: Multilingual Matters.

Milani, T. M., Davies, B., \& Turner, W. (2011). Unity in disunity: Centripetal and centrifugal tension on the BBC voices website. Journal of Language and Politics, 10(4), 587-614.

Nelde, P., et al. (1996). Euromosaic: The production and reproduction of the minority language groups of the European union. Brussels: European Commission.

Office for National Statistics. (2012). 2011 Census: First results on the Welsh language. http://wales.gov. uk/docs/statistics/2012/121211sb1182012en.pdf. Accessed December 2014.

Osmond, J. (1992). Miliwn yn Mudo. In Ll. Dafis (Ed.), Yr Ieithoedd Llai - Cymhathu NewyddDdyfodiaid (pp. 1-7). Y Lolfa: Tal-y-Bont.

Paulston, C. B. (1992). Sociolinguistic perspectives on bilingual education. Clevedon: Multilingual Matters.

Ricento, T. K. (Ed.). (2006). An introduction to language policy: Theory and method. Malden MA: Blackwell Publishing.

Ricento, T. K., \& Hornberger, N. H. (1996). Unpeeling the onion: Language planning and policy and the ELT professional. TESOL Quarterly, 30(3), 401-427.

Romaine, S. (2002). The impact of language policy on endangered languages. International Journal on Multicultural Societies, 4(2), 194-212.

Royles, E. (2007). Revitalizing democracy?: Devolution and civil society in Wales. Cardiff: University of Wales Press.

Scully, R. (2013). The electoral state of the parties 1: Labour. http://www.clickonwales.org/2013/08/theelectoral-state-of-the-parties-1-labour/. Accessed December 2014.

Skutnabb-Kansas, T. (1990). Language, literacy and minorities. London: The Minority Rights Group.

Tollefson, J. W. (1991). Planning language. Planning inequality. Language policy in the community. London: Longman.

Tollefson, J. W. (1995). Power and inequality in language education. Cambridge: Cambridge University Press.

Tollefson, J. W. (Ed.). (2002). Language policies in education: Critical issues (1st ed.). New York: Routledge.

Tollefson, J. W. (Ed.). (2013). Language policies in education (2nd ed.). London: Routledge.

Trystan, D., Scully, R., \& Wyn Jones, R. (2003). Explaining the quiet earthquake: Voting behaviour in the first election to the national assembly for Wales. Electoral Studies, 22, 635-650.

Utgorn. (2006). Ymchwil Dirgel i Ganfod Llwyddiant Dosbarthu Pecyn Croeso Bwrdd yr Iaith Gymraeg. Porthmadog: Utgorn.

Welsh Government. (2003). Iaith Pawb-A national action plan for a bilingual Wales. Cardiff: Welsh Government.

Welsh Government. (2007). One Wales-A progressive agenda for the government of Wales. Cardiff: Welsh Government.

Welsh Government. (2010). Welsh-medium education strategy. Cardiff: Welsh Government.

Welsh Government. (2012). Iaith Fyw: Iaith Byw. Cardiff: Welsh Government.

Welsh Government. (2013). Migration statistics: Wales 2011. http://gov.wales/docs/statistics/2013/ 130312-migration-statistics-2011-en.pdf. Accessed August 2015.

Welsh Language Board. (2003). Rhyddid Mynegiant a Harmoni Ieithyddol yng Nghymru. Cardiff: Welsh Language Board.

Welsh Language Board. (2005). Dyfodol y Gymraeg—Cynllun strategol: The future of Welsh-A strategic plan. Cardiff: Welsh Language Board.

Welsh Language (Wales) Measure. (2011). http://www.legislation.gov.uk/mwa/2011/1/pdfs/mwa_ 20110001_en.pdf. Accessed July 2013.

Welsh Language Board. (2006). Adroddiad Blynyddol. Cynllun Cymhathu Mewnfudwyr Llŷn. 2005-2006. Cardiff: Welsh Language Board.

Welsh Mirror. (2001a). Voice of hate. 18 Jan, pp. 1-2.

Welsh Mirror. (2001b). Group in home office racism row. 7 Nov, p. 1. 
Wiley, T. G. (2013). A brief history and assesment of language rights in the United States. In J. W. Tollefson (Ed.), Language policies in education (2nd ed., pp. 61-90). London: Routledge.

Williams, C. H. (1998). Operating through two languages. In The national assembly agenda (Ed.), Osmond, J. Cardiff: Institute of Welsh Affairs.

Williams, C. H. (2000). Language revitalization: Policy and planning and Wales. Cardiff: University of Wales Press.

Williams, C. H. (2005). Iaith Pawb: The Doctrine of Plenary Inclusion. Contemporary Wales, 17(1), 1-27.

Wodak, R., \& Meyer, M. (2009). Critical discourse analysis: History, agenda, theory and methodology. In R. Wodak \& M. Meyer (Eds.), Methods of critical discourse analysis (2nd ed., pp. 1-33). London: Sage.

Wyn Jones, R. (2014). The fascist party in Wales? Plaid Cymru, Welsh nationalism and the accusation of fascism. Chicago: The University of Chicago Press.

Wyn Jones, R., \& Trystan, D. A. (2000). 'Quiet earthquake': The first national elections to the national assembly for Wales. CREST Working Paper. 85.

Wynne Jones, I. (1986). Border line. In Daily post (Liverpool). 9 August 1986.

Cartin Wyn Edwards is a Lecturer in International Politics in the Department of International Politics at Aberystwyth University. She previously worked as a Post-Doctoral Researcher at the School of Political studies at University of Ottawa (Canada). Her research interests include language policy and politics, immigration policy, multiculturalism and linguistic diversity. 